\title{
A Concise and Selective Synthesis of Novel 5-Aryloxy Imidazole NNRTIs
}

\section{Lyn H. Jones, ${ }^{*}$ Thomas Dupont, Charles E. Mowbray, Sandra D. Newman}<smiles>CNC(=O)C(C)N</smiles>

Prepared according to J. Med. Chem. 1987, 30, 567. Identical by ${ }^{1} \mathrm{H}$ NMR.

6<smiles>CC1=NC(C)C(=O)N1C</smiles>

Known compound: Bull. Soc. Chim. Belg 1976, 85, 573.

Triethylorthoacetate $(6 \mathrm{mmol}, 1.1 \mathrm{~mL})$ and aminoamide $5(5 \mathrm{mmol}, 510 \mathrm{mg})$ were heated to $100^{\circ} \mathrm{C}$ for $3 \mathrm{hrs}$ under a nitrogen atmosphere. After $1 \mathrm{hr}$ another $300 \mu \mathrm{L}$ triethylorthoacetate were added. Reaction complete after a further $1 \mathrm{hr}$ (reaction followed by ${ }^{1} \mathrm{H} \mathrm{NMR}$ ), therefore concentrated in vacuo and purified by FCC (silica gel, mesh, $5 \% \mathrm{MeOH} / \mathrm{DCM})$ to yield 6 as a colourless oil $\left(355 \mathrm{mg}, 56 \%\right.$ yield): ${ }^{1} \mathrm{H}$ NMR $\left(\mathrm{CDCl}_{3}, 400 \mathrm{MHz}\right) 1.36(\mathrm{~d}, 3 \mathrm{H}), 2.22(\mathrm{~s}, 3 \mathrm{H}), 3.05(\mathrm{~s}, 3 \mathrm{H}), 3.98(\mathrm{~m}, 1 \mathrm{H})$; IR (thin film) 1721, $1642 \mathrm{~cm}^{-1}$; mass spectrum (APCI+) $127(\mathrm{M}+\mathrm{H}, 100 \%)$; LCMS (ELSD) $>95 \%(127, \mathrm{M}+\mathrm{H})$.

8

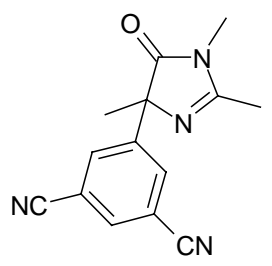

Imidazolone 6 (0.5 mmol, $63 \mathrm{mg})$ was dissolved in DMF $(0.5 \mathrm{~mL}), 3,5-$ dicyanofluorobenzene $7(0.5 \mathrm{mmol}, 73 \mathrm{mg})$ then potassium carbonate $(0.5 \mathrm{mmol}, 69$ $\mathrm{mg}$ ) were added and the mixture was heated to $120^{\circ} \mathrm{C}$ under a nitrogen atmosphere. After $1 \mathrm{hr}$ the reaction was quenched with water, extracted (EtOAc), dried $\left(\mathrm{MgSO}_{4}\right)$, filtered and concentrated under reduced pressure. The crude mixture was purified by FCC (silica gel, mesh, 5\% MeOH/DCM) to yield 8 as a white amorphous solid (12 mg, 10\% yield): ${ }^{1} \mathrm{H}$ NMR ( $\left.\mathrm{CDCl}_{3}, 400 \mathrm{MHz}\right) 1.62$ (s, 3H), 2.35 (s, 3H), 3.09 (s, 3H), 


\section{S2}

$7.82(\mathrm{~s}, 1 \mathrm{H}), 8.20(\mathrm{~s}, 2 \mathrm{H})$; IR (solid) 1721, $1642 \mathrm{~cm}^{-1}$; mass spectrum (APCI+) 253 (M+H, 100\%); LCMS (ELSD) >90\% (253, M+H); HMBC attached.

9

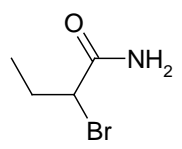

Prepared according to Chem. Pharm. Bull. 1987, 35, 2243. Identical by ${ }^{1} \mathrm{H}$ NMR.

10

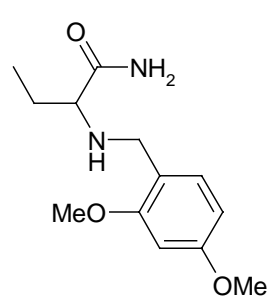

Bromide 9 (21.7 mmol, $3.6 \mathrm{~g})$ was dissolved in tetrahydrofuran (50 $\mathrm{mL})$, triethylamine $(65 \mathrm{mmol}, 10 \mathrm{~mL})$ and 2,4-dimethoxybenzylamine hydrochloride salt ( $26 \mathrm{mmol}, 5.3 \mathrm{~g}$ ) were added and the mixture stirred at $105 \mathrm{oC}$ for 3 days. The mixture was cooled to room temperature, filtered and concentrated under reduced pressure, the residue was triturated with diethyl ether to yield $\mathbf{1 0}$ as a white solid(4.3 $\mathrm{g}, 80 \%$ yield): ${ }^{1} \mathrm{H}$ NMR $\left(\mathrm{CDCl}_{3}, 400 \mathrm{MHz}\right) 0.90(3 \mathrm{H}, \mathrm{t}), 1.56(1 \mathrm{H}, \mathrm{m}), 1.75(1 \mathrm{H}, \mathrm{m}), 2.15(1 \mathrm{H}, \mathrm{bs})$, $3.02(1 \mathrm{H}, \mathrm{m}), 3.55(1 \mathrm{H}, \mathrm{d}), 3.73-3.81(7 \mathrm{H}, \mathrm{m}), 5.49(1 \mathrm{H}, \mathrm{bs}), 6.38-6.43(2 \mathrm{H}, \mathrm{m}), 7.06$ $(1 \mathrm{H}, \mathrm{m}), 7.42(1 \mathrm{H}, \mathrm{bs})$; mass spectrum $(\mathrm{APCI}+) 253(\mathrm{M}+\mathrm{H}, 100 \%)$; LCMS (ELSD) $>95 \%\left(225, \mathrm{M}-2 \mathrm{CH}_{2}\right)$.

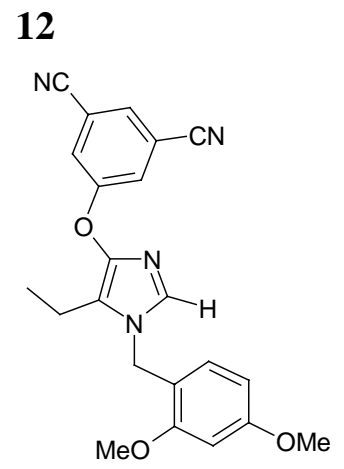

Amino amide 10 (10.6 mmol, $2.7 \mathrm{~g}$ ) was suspended in triethylorthoformate (20 mL), heated to $150^{\circ} \mathrm{C}$ and a catalytic amount of acetic acid was added. After 2 hours the 


\section{S3}

mixture was cooled to room temperature and concentrated under reduced pressure to yield 11 as a white solid which was used crude in the next step. 11 was dissolved in DMSO $(20 \mathrm{~mL})$ potassium carbonate $(10.6 \mathrm{mmol}, 1.5 \mathrm{~g})$ was added and the mixture stirred at room temperature for 3 minutes, then 3,5-dicyanofluoro benzene (10.6 mmol, $1.6 \mathrm{~g}$ ) was added and the mixture was stirred at $100 \mathrm{oC}$ for 4 hours. The mixture was cooled, brine added, extracted (EtOAc), dried $\left(\mathrm{MgSO}_{4}\right)$, filtered and concentrated under reduced pressure. The crude mixture was purified by FCC (silica gel, mesh, 33\% EtOAc/pentane) to yield $\mathbf{1 2}$ as a white amorphous solid (1.9 g, $46 \%$ yield over two steps): ${ }^{1} \mathrm{H}$ NMR $\left(\mathrm{CDCl}_{3}, 400 \mathrm{MHz}\right) 1.08(3 \mathrm{H}, \mathrm{t}), 2.52(2 \mathrm{H}, \mathrm{q}), 3.78$ $(3 \mathrm{H}, \mathrm{s}), 3.81(3 \mathrm{H}, \mathrm{s}), 4.86(2 \mathrm{H}, \mathrm{s}), 6.46(2 \mathrm{H}, \mathrm{m}), 6.92(1 \mathrm{H}, \mathrm{m}), 7.28(1 \mathrm{H}, \mathrm{s}), 7.50(2 \mathrm{H}$, s), $7.57(1 \mathrm{H}, \mathrm{s})$; IR (solid) $1582,1425 \mathrm{~cm}^{-1}$; mass spectrum (APCI+) 389 (M+H, $100 \%)$; LCMS (ELSD) >95\% (389, M+H).

\section{3}

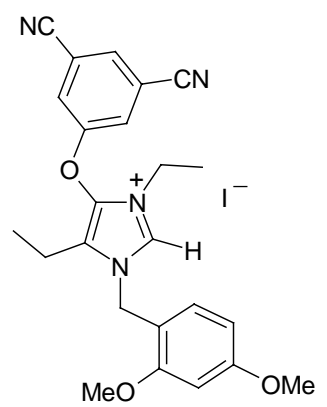

Imidazole 12 (3.9 mmol, $1.5 \mathrm{~g})$ was dissolved in ethyl iodide $(30 \mathrm{~mL})$ and heated to reflux, after 18 hours the mixture was cooled and the product precipitated out, which was filtered and washed with diethyl ether to yield $\mathbf{1 3}$ as a white solid $(1.85 \mathrm{~g}, 88 \%$ yield): ${ }^{1} \mathrm{H}$ NMR $\left(\mathrm{CDCl}_{3}, 400 \mathrm{MHz}\right) 1.08(3 \mathrm{H}, \mathrm{t}), 1.47(3 \mathrm{H}, \mathrm{t}), 2.65(2 \mathrm{H}, \mathrm{q}), 3.81(3 \mathrm{H}$, s), $3.87(3 \mathrm{H}, \mathrm{s}), 4.12(2 \mathrm{H}, \mathrm{q}), 5.35(2 \mathrm{H}, \mathrm{s}), 6.47(1 \mathrm{H}, \mathrm{m}), 6.53(1 \mathrm{H}, \mathrm{m}), 7.60(1 \mathrm{H}, \mathrm{d})$, $7.75(1 \mathrm{H}, \mathrm{m}), 7.92(2 \mathrm{H}, \mathrm{s}), 9.19(1 \mathrm{H}, \mathrm{s})$; mass spectrum (APCI-) 416 (M-H-I, 100\%); LCMS (ELSD) $>95 \%$ (416, M-H-I).

\section{4}

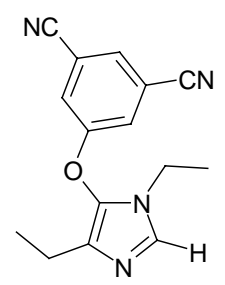

Imidazolonium salt 13 (3.4 mmol, $1.85 \mathrm{~g})$ was dissolved in dichloromethane (100 $\mathrm{mL}$ ), cooled to $0^{\circ} \mathrm{C}$ and boron tribromide $(34 \mathrm{mmol}, 3.0 \mathrm{~mL}$ ) was added dropwise and the mixture was warmed to room temperature. After 30 minutes the mixture was 


\section{S4}

quenched with $1 \mathrm{~N}$ sodium hydroxide solution, extracted (EtOAc), dried $\left(\mathrm{MgSO}_{4}\right)$, filtered and concentrated under reduced pressure. The crude mixture was purified by FCC (silica gel, mesh, 5\% MeOH/EtOAc) to yield $\mathbf{1 4}$ as a white amorphous solid (770 mg, 80\% yield): ${ }^{1} \mathrm{H}$ NMR $\left(\mathrm{CDCl}_{3}, 400 \mathrm{MHz}\right) 1.13(3 \mathrm{H}, \mathrm{t}), 1.32(3 \mathrm{H}, \mathrm{t}), 2.36$ $(2 \mathrm{H}, \mathrm{q}), 3.73(2 \mathrm{H}, \mathrm{q}), 7.40(2 \mathrm{H}, \mathrm{s}), 7.48(1 \mathrm{H}, \mathrm{s}), 7.66(1 \mathrm{H}, \mathrm{s})$; IR (solid) 1579, 1498, 1424, $1415 \mathrm{~cm}^{-1}$; mass spectrum (APCI+) $267(\mathrm{M}+\mathrm{H}, 100 \%)$; LCMS (ELSD) $>95 \%$ (267, M+H); EA calculated C: $67.65 \%, \mathrm{H}: 5.30 \%, \mathrm{~N}: 21.04 \%$; observed C: $67.31 \%$, H: $5.32 \%, \mathrm{~N}: 20.31 \%$.

15

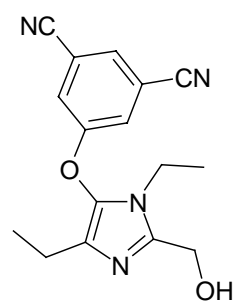

Imidazole 14 (3.38 mmol, $900 \mathrm{mg}$ ), paraformaldehyde (34 mmol, $989 \mathrm{mg}$ ), powdered 3 angstrom molecular sieves $(200 \mathrm{mg})$ and DMSO $(5 \mathrm{~mL})$ were heated together in a sealed vessel to $140^{\circ} \mathrm{C}$. After 5 hours the mixture was cooled and saturated sodium bicarbonate was added and the mixture extracted (EtOAc), dried $\left(\mathrm{MgSO}_{4}\right)$, filtered and concentrated under reduced pressure. The crude mixture was purified by FCC (silica gel, mesh, 5\% MeOH/EtOAc) to yield $\mathbf{1 5}$ as pale yellow solid (1.05 g, 99\% yield): ${ }^{\mathrm{T}} \mathrm{H} \mathrm{NMR}\left(\mathrm{CDCl}_{3}, 400 \mathrm{MHz}\right) 1.13(3 \mathrm{H}, \mathrm{t}), 1.30(3 \mathrm{H}, \mathrm{t}), 2.38(2 \mathrm{H}, \mathrm{q}), 3.87(2 \mathrm{H}$, q), $4.70(2 \mathrm{H}, \mathrm{s}), 7.43(2 \mathrm{H}, \mathrm{s}), 7.66(1 \mathrm{H}, \mathrm{s})$; IR (solid) 3200, 1582, 1426, $1407 \mathrm{~cm}^{-1}$; mass spectrum (APCI+) 297 (M+H, 100\%); LCMS (ELSD) 92\% (297, M+H); EA calculated C: $64.85 \%, \mathrm{H}: 5.44 \%, \mathrm{~N}: 18.91 \%$; observed C: $64.45 \%, \mathrm{H}: 5.44 \%, \mathrm{~N}$ : $18.64 \%$.

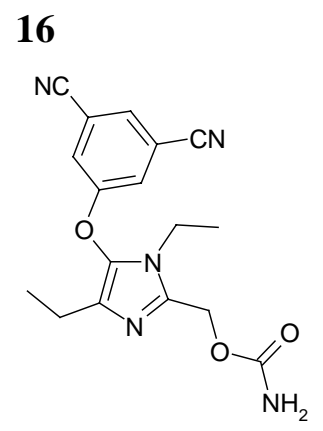

Alcohol $15(0.20 \mathrm{mmol}, 60 \mathrm{mg})$ was dissolved in THF $(2 \mathrm{~mL})$, cooled to $0^{\circ} \mathrm{C}$, trichloroacetyl isocyanate $(0.22 \mathrm{mmol}, 29 \mu \mathrm{L})$ was added and after 3 hours warmed to room temperature. Saturated sodium bicarbonate solution was added, extracted (DCM) and loaded onto a short column of basic alumina and after 5 minutes the 
product was eluted with EtOAc. Diethyl ether was added to crystallise the product which was triturated with diisopropyl ether to yield 16 as a white solid (53 $\mathrm{mg}, 79 \%$ yield): ${ }^{1} \mathrm{H} \mathrm{NMR}\left(\mathrm{CDCl}_{3}, 400 \mathrm{MHz}\right) 1.18(3 \mathrm{H}, \mathrm{t}), 1.28(3 \mathrm{H}, \mathrm{t}), 2.40(2 \mathrm{H}, \mathrm{q}), 3.85(2 \mathrm{H}$, t), $4.85(2 \mathrm{H}, \mathrm{bs}), 5.20(2 \mathrm{H}, \mathrm{s}), 7.49(2 \mathrm{H}, \mathrm{s}), 7.69(1 \mathrm{H}, \mathrm{s})$; IR (solid) 3126, 1731, 1716, $1582 \mathrm{~cm}^{-1}$; mass spectrum (APCI+) $340(\mathrm{M}+\mathrm{H}, 100 \%)$; LCMS (ELSD) >95\% (340, $\mathrm{M}+\mathrm{H})$; EA calculated C: $59.23 \%, \mathrm{H}: 5.15 \%, \mathrm{~N}: 20.31 \%$; observed C: $58.98 \%, \mathrm{H}$ : $5.13 \%, \mathrm{~N}: 20.06 \%$.

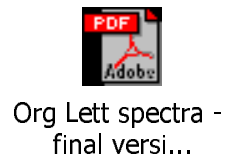

\section{Summary of method to determine potencies}

The assay uses a DNA/RNA primer/template where the 5' biotinylated primer DNA is a 16 mer oligo $\mathrm{d}(\mathrm{T})$ and is annealed to a poly(rA) template, approximately 300 bases in length. Incorporation of $\left[{ }^{3} \mathrm{H}\right] \mathrm{TTP}$ by reverse transcription, results in extension of the primer. During the reaction the primer/template is bound to a streptavidin-coated 'flashplate'. The incorporated tritiated nucleotides can then stimulate the scintillant to produce a signal that is measured using a scintillation counter. Compounds that inhibit reverse transcription will give rise to a reduced signal and a dose-response curve for each compound can be used to calculate the $\mathrm{IC}_{50}$ values. 